\title{
Shackleton Fracture Zone: No barrier to early circumpolar
}

\section{ocean circulation}

\author{
Roy Livermore British Antarctic Survey, High Cross, Madingley Road, Cambridge CB3 OET, UK \\ Graeme Eagles Alfred Wegener Institute for Polar Research, Columbusstrasse, 27568 Bremerhaven, Germany \\ Peter Morris British Antarctic Survey, High Cross, Madingley Road, Cambridge CB3 OET, UK \\ Andres Maldonado Instituto Andaluz de Ciencias de la Tierra, C.S.I.C., Universidad de Granada, Campus de Fuentenueva, \\ s/n, 18002 Granada, Spain
}

\section{ABSTRACT}

The opening of Southern Ocean gateways was critical to the formation of the Antarctic Circumpolar Current and may have led to Cenozoic global cooling and Antarctic glaciation. Drake Passage was probably the final barrier to deep circumpolar ocean currents, but the timing of opening is unclear, because the Shackleton Fracture Zone could have blocked the gateway until the early Miocene. Geophysical and geochemical evidence presented here suggests that the Shackleton Fracture Zone is an oceanic transverse ridge, formed by uplift related to compression across the fracture zone since ca. 8 Ma. Hence, there was formerly (i.e., in the Miocene) no barrier to deep circulation through Drake Passage, and a deepwater connection between the Pacific and Atlantic Oceans was probably established soon after spreading began in Drake Passage during the early Oligocene.

Keywords: gateways, Southern Ocean, Antarctic Circumpolar Current, Shackleton Fracture Zone, transverse ridge.

\section{INTRODUCTION}

The opening of Drake Passage between South America and Antarctica (Fig. 1) has generally been regarded as a critical step leading to global cooling and Antarctic glaciation by removing the final barrier to deep circumpolar ocean circulation (Barker, 2001). The consequent development of the Polar Front and onset of the Antarctic Circumpolar Current led to the thermal isolation of Antarctica (Kennett et al., 1975; Kennett, 1977).

There is currently a debate concerning the relative importance of Southern Ocean gateways (e.g., Exon et al., 2002), declining $\mathrm{CO}_{2}$ (e.g., DeConto and Pollard, 2003), and closure of low-latitude gateways (e.g., Lawver and Gahagan, 1998) for Cenozoic climate evolution and, in particular, the abrupt Eocene-Oligocene cooling/glaciation event ( $\mathrm{Za}$ chos et al., 2001). Numerical studies using global general circulation models have attempted to evaluate the world-climate implications of the first shallow- and deep-water connections through the Drake Passage gateway, with disparate results (e.g., Mikolajewicz et al., 1993; Nong et al., 2000; DeConto and Pollard, 2003; Sijp and England, 2004). DeConto and Pollard (2003) suggested, on the basis of coupled climate-ice-sheet simulations, that $\mathrm{CO}_{2}$ decline was the prime cause of abrupt Eocene-Oligocene (ca. $33 \mathrm{Ma}$ ) cooling and that opening of Southern Ocean gateways played only a minor role. Sijp and England (2004), using a coupled ocean-atmosphere model of intermediate complexity, concluded that opening to shallow depths was sufficient to bring about Southern Hemisphere cooling and a significant increase in Antarctic sea ice, but North Atlantic thermohaline circulation and Northern Hemisphere warming occurred only when Drake Passage opened to full ocean depths.

In the much-cited model for Drake Passage opening of Barker and Burrell (1977), seafloor spreading was initiated at some time prior to magnetic chron C8 (26 Ma), and perhaps prior to C10 (29 Ma), as indicated by the oldest identified magnetic anomalies, but deep-water flow was inhibited by continental slivers along the Shackleton Fracture
Zone (Fig. 1), which overlapped each other until ca. 23.5 Ma, i.e., well after the Eocene-Oligocene cooling event. If correct, this scenario would favor the interpretation of DeConto and Pollard (2003), implying that global cooling occurred before the development of a deep connection at Drake Passage.

Although the implications for global climate are profound, the "overlapping continental slivers" hypothesis has never been fully tested. However, there are geophysical and geochemical data that permit us to reexamine the question of whether these slivers, in particular the ridge parallel to the southeast section of the Shackleton Fracture Zone, are continental in nature.

\section{SHACKLETON TRANSVERSE RIDGE}

It is important to note that the Shackleton Fracture Zone is not the product of tectonics at a simple ridge-transform-ridge offset. In fact, the entire length has always been tectonically active during its evolution as a boundary between plates in the Scotia Sea and southeast Pacific Ocean since the Eocene. Prior to extinction of the West Scotia

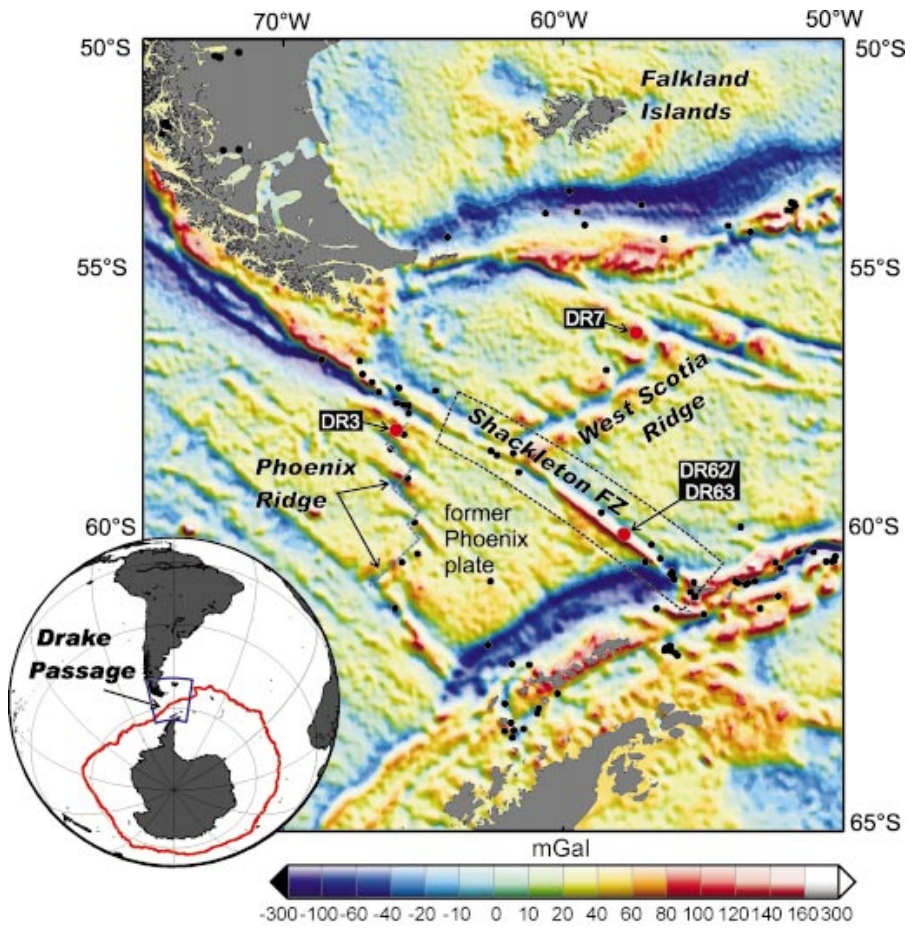

Figure 1. Map of Drake Passage and environs, showing free-air gravity anomalies from Sandwell and Smith (1997). Superimposed are relocated earthquake epicenters from Engdahl et al. (1998) (black dots) and rock-dredge sites (red circles). Dotted box shows extent of mapped area in Figure 2. Southeastward along Shackleton Fracture Zone (FZ) from its intersection with West Scotia Ridge is Shackleton transverse ridge, bathymetric feature named in this paper and shown in more detail in Figure 2. Inset: Location of Drake Passage, showing Polar Front (red line) and area represented by main map (blue box). 
Figure 2. A: Tectonic summary map of southeastern Shackleton Fracture Zone. Features labeled are discussed in text. Projection is oblique Mercator, projected about pole $\left(68^{\circ} \mathrm{S}, 76^{\circ} \mathrm{W}\right)$. Shallow earthquake epicenters (Engdahl et al., 1998; yellow stars), Harvard Centroid Moment Tensor solutions (black beach balls), and focal mechanisms from Pelayo and Wiens (1989; blue beach balls) are also shown. Small arrows along Shackleton Fracture Zone (bold black line) represent AntarcticaScotia plate motion with rates shown in shaded rectangles, calculated from model TLP2003 (Thomas et al., 2003). Large arrows at West
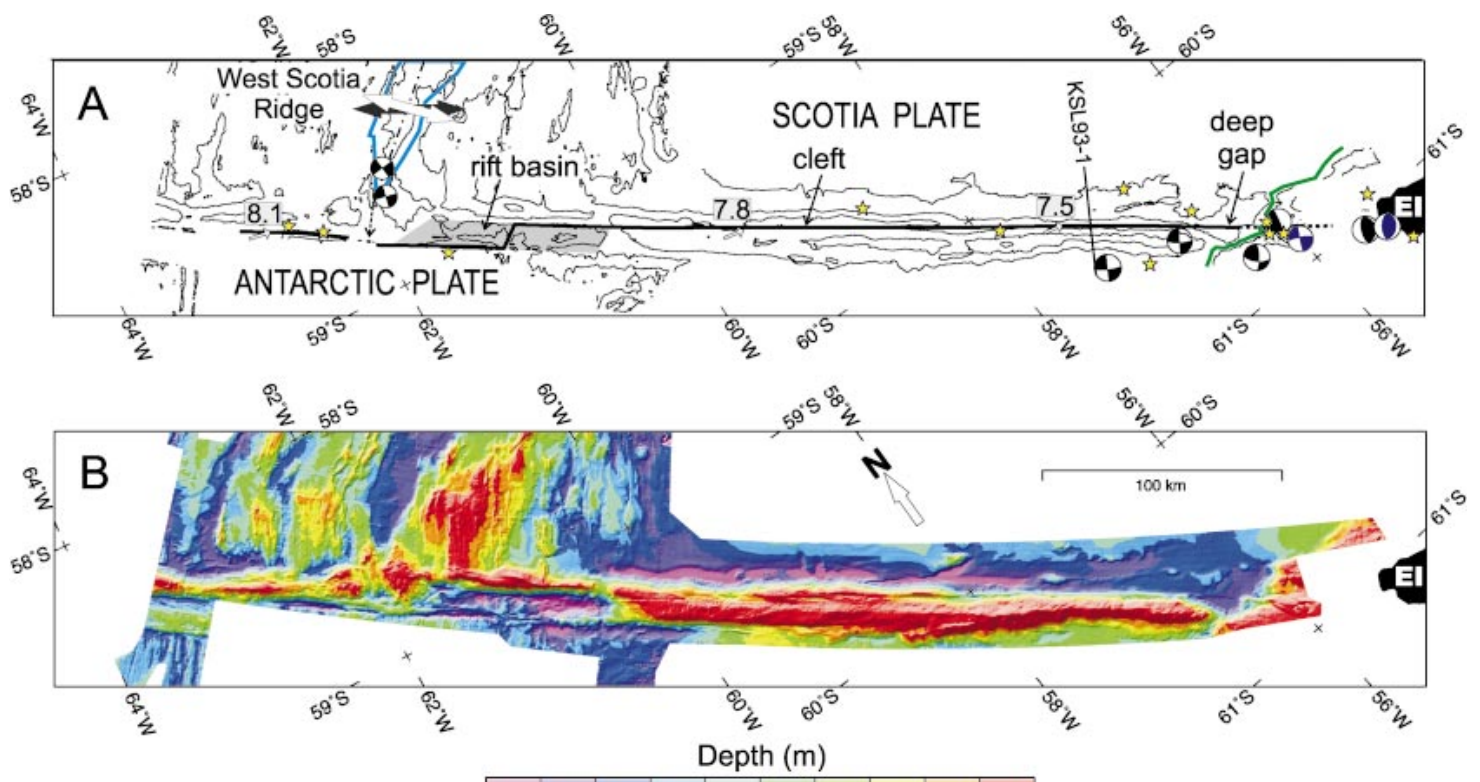

Scotia Ridge axis indicate direction of spreading before (black) and during (white) final, oblique, phase of spreading between 8 and 6.5 Ma. Deep basin (shaded) is interpreted as pull-apart feature. Location of seismic reflection profile KSL93-1 (Kim et al., 1997) is shown. Green line-2000 m isobath representing approximate position of Antarctic continental edge; blue line-outline of median valley of extinct West Scotia Ridge spreading center. B: High-resolution bathymetry of Shackleton Fracture Zone and adjacent parts of Antarctic Peninsula margin (EI-Elephant Island) and West Scotia Ridge, obtained with hull-mounted multibeam echo sounders fitted to BIO Hesperides and RRS James Clark Ross.

Ridge ca. 6.5 Ma (Maldonado et al., 2000), it separated the two plates formed at the fast-intermediate-spreading Phoenix Ridge (Livermore et al., 2000; Eagles, 2003) in the southwest (Fig. 1) from the two plates created at the intermediate-slow-spreading West Scotia Ridge (Livermore et al., 1994) to the northeast. Since extinction of the Phoenix Ridge ca. 3.3 Ma (Livermore et al., 2000; Eagles, 2003), the Shackleton Fracture Zone has formed part of the Antarctic-Scotia plate boundary.

In its southeastern section, the fracture zone is flanked by a narrow $(\sim 15 \mathrm{~km})$, steep-sided feature that we refer to as the Shackleton transverse ridge. This ridge has been mapped in detail (Fig. 2) as part of a continuing effort by the British Antarctic Survey and the University of Granada, using multibeam echo sounders fitted to RRS James Clark Ross and BIO Hesperides. These data show that the transverse ridge is a continuous feature between $61^{\circ} 40^{\prime} \mathrm{W}$ and $56^{\circ} 40^{\prime} \mathrm{W}$, being widest $(\sim 20 \mathrm{~km})$ between $60^{\circ} 20^{\prime} \mathrm{W}$ and $58^{\circ} 0^{\prime} \mathrm{W}$. The elevation of the ridge tends to increase toward the southeast and is highest near $60^{\circ} 10^{\prime} \mathrm{S}$, $57^{\circ} 40^{\prime} \mathrm{W}$, where it shoals to $\sim 750 \mathrm{~m}$, whereas oceanic crust on either side of the ridge increases in age, and therefore deepens, toward the Antarctic margin.

It is clear from Figure 2 that the transverse ridge is separated from the Antarctic continental margin at its southeastern end by a deep gap (depth > 3000 m; see also Klepeis and Lawver, 1996) and appears to be structurally distinct. This circumstance argues against an interpretation in which the ridge is assumed to be an extension of the Antarctic continental margin (Barker and Burrell, 1977). The northwestern termination of the transverse ridge is $\sim 25 \mathrm{~km}$ from the intersection between the Shackleton Fracture Zone and the axis of the now-inactive West Scotia Ridge. Within this zone, the West Scotia Ridge seems to have propagated southwestward into the fracture zone prior to extinction (Fig. 2). The abandoned ridge axis is marked by a topographic high flanked by shallow crust with a well-developed abyssal-hill fabric, suggesting enhanced volcanism immediately prior to extinction. This topography contrasts with the deep median valley found elsewhere along the West Scotia Ridge axis.

In the new bathymetric data, a narrow cleft is observed that extends parallel to the axis of the transverse ridge on its northeastern flank (Fig. 2), from $\sim 58^{\circ} \mathrm{W}$ to $60^{\circ} 20^{\prime} \mathrm{W}$, and probably marks the surface expression of recent strike-slip motion. The few earthquakes recorded from the vicinity have focal mechanisms indicating sinistral strike-slip faulting, subparallel to this cleft, although it may be seen by comparison with Antarctica-Scotia vectors from relative-motion model TLP2003 (Thomas et al., 2003; Fig. 2) that a small compressional component must also be accommodated. Earthquake and topographic evidence strongly suggests that the Antarctic-Scotia plate boundary crosses to the southwest side of the fracture zone west of $61^{\circ} 10^{\prime} \mathrm{W}$. A short segment linking the two would create a releasing bend, explaining the presence of the deep basin (shaded in Fig. 2A) at the northwest end of the transverse ridge as a pull-apart feature.

\section{BASALT GEOCHEMISTRY}

Two dredge hauls, DR62 and DR63, were collected near the shallowest part of the Shackleton transverse ridge (Fig. 1) in water depths of $1760 \mathrm{~m}$ and $2920 \mathrm{~m}$, respectively, and recovered mainly basaltic material. Analyses of trace elements by inductively coupled plasmamass spectrometry (Pearce et al., 2001) show that samples from these dredge hauls have enriched mid-oceanic-ridge basalt (E-MORB) compositions (Fig. 3), with elevated concentrations of large ion lithophile elements and light rare earth elements relative to normal (N) MORB. Two samples are particularly enriched, whereas the other two are very similar to compositions of samples dredged from the Phoenix Ridge (DR3) to the southwest, and from the West Scotia Ridge (DR7) to the northeast. The higher degree of enrichment may be a result of the cooling effect of the fracture zone, producing a lower degree of melting on the adjacent segment end. E-MORBs are also found at the Romanche (Bonatti et al., 1994) and Macquarie (Kamenetsky et al., 2000) 


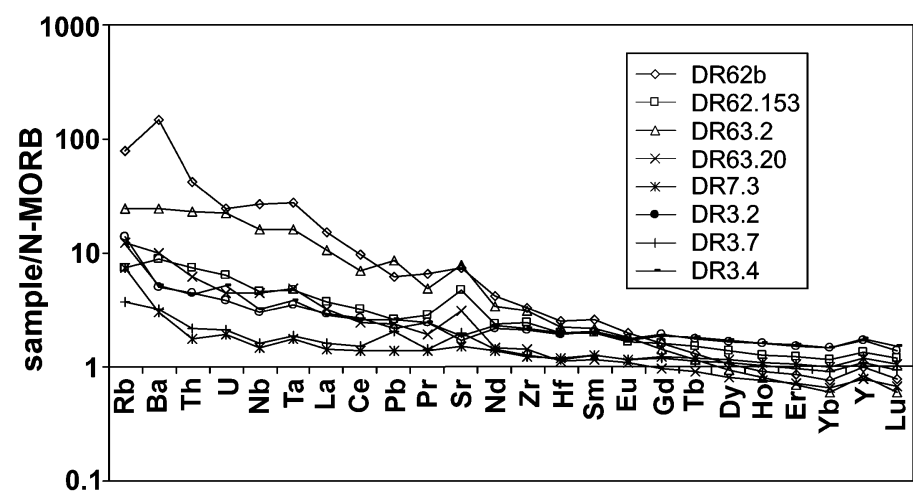

Figure 3. Trace element analyses of dredged samples from Shackleton Ridge (DR62, DR63) and West Scotia Ridge (DR7), normalized to global mid-oceanic-ridge basalt (N-MORB) composition of Sun and McDonough (1989). Data are from Pearce et al. (2001). Note that Shackleton Ridge samples DR62.153 and DR63.20 have compositions very similar to those from Phoenix Ridge (DR3).

Fracture Zones, both with large age offsets and transverse ridges. Hence these basalts are consistent with a purely oceanic origin of the Shackleton transverse ridge, which must therefore represent either abnormally thick or uplifted ocean lithosphere.

\section{SEISMIC REFLECTION PROFILES}

Marine seismic reflection profiles have been acquired across the Shackleton transverse ridge (Klepeis and Lawver, 1996; Kim et al., 1997; Maldonado et al., 2000), most of which show a very slightly asymmetrical, flat-sided feature, free of sediments and lacking internal reflections. These characteristics are typical of oceanic transverse ridges. Representative seismic reflection profiles across the Shackleton (Kim et al., 1997) and Vema (Bonatti et al., 2003) transverse ridges, plotted with the same horizontal scale and vertical exaggeration, are shown in Figure 4.

The Vema transverse ridge has probably been elevated since 6.6 Ma, following a small change in the South America-Africa pole of rotation (Kastens et al., 1998), and provides a remarkable section through oceanic lithosphere (Bonatti et al., 2003). The similarity between the seismic character of this undoubtedly oceanic feature and that of the Shackleton transverse ridge is striking. Furthermore, modeling of gravity anomalies over the two ridges produced very similar results (Kim et al., 1997; Prince and Forsyth, 1988), indicating slight crustal thinning beneath the axes of the transverse ridges. Although smaller than the Shackleton transverse ridge, the well-studied Clipperton Fracture Zone ridge also shows many of the same features (Pockalny, 1997), and, like the Shackleton Fracture Zone, the active trace is marked by a narrow cleft. In this case, uplift of the transverse ridge can be related to changes in motion between the Pacific and Cocos plates since 2.5 Ma.

\section{DISCUSSION}

Continental slivers are known from various plate tectonic settings, including the small fragments rifted during Gondwana breakup (e.g., Smith, 1999) and exotic terranes such as those transported along the North American margin by interaction with the Pacific plate (e.g., Coney et al., 1980). However, none of these resembles the Shackleton transverse ridge, either in their morphology or their geometry with respect to plate boundaries. Although continental material may be incorporated into fracture zones (e.g., Gasperini et al., 2001), transverse ridges are formed by uplift of oceanic lithosphere in response to plate interactions at fracture zones and are not primary features. Proposed uplift mechanisms (Bonatti, 1978; Kastens et al., 1998) include mantle hydration, excess volcanism, and compressive stress. Studies of trans-
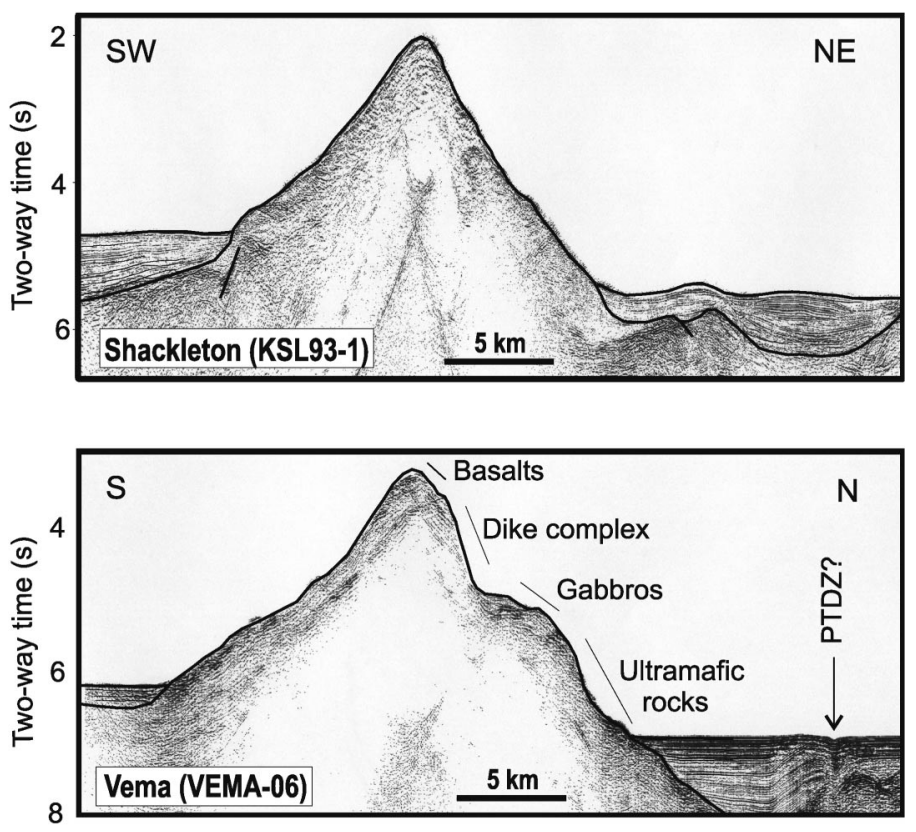

Figure 4. Seismic reflection profiles across Shackleton (location shown in Fig. 2) and Vema transverse ridges. KSL93-1 is reproduced from Kim et al. (1997); VEMA-06 is from Bonatti et al. (2003). PTDZprincipal transform displacement zone.

verse ridges in the Atlantic Ocean (Bonatti et al., 1994, 2003; Kastens et al., 1998; Prince and Forsyth, 1988) and Pacific Ocean (Pockalny et al., 1997; Deschamps et al., 1998) all favor a model involving uplift of the plate edge resulting from small changes in the Euler pole of relative motion between the flanking plates. Although the precise mechanism is unclear, and probably varies between the different classes of fracture zone ridge, such a model implies that transverse ridges are uplifted as a unit over a period perhaps as short as a few million years (Kastens et al., 1998).

Applying these findings to the Shackleton transverse ridge, we suggest that uplift probably occurred as a result of transpression between the adjacent Phoenix (Fig. 1) and Scotia plates at the fracture zone. The most likely time for uplift was during a period of regional Scotia Sea compression after 17 Ma (Eagles, 2000), which eventually led to the extinction of the West Scotia Ridge ca. 6.5 Ma (Maldonado et al., 2000) and was followed by extinction of the Phoenix Ridge at 3.3 Ma (Livermore et al., 2000). Evidence of late-stage compression in the west Scotia Sea has been presented previously (Maldonado et al., 2000) and includes thrusting and crustal thickening (FloresMárquez et al., 2003) observed on the southeast flank of the West Scotia Ridge. This compression probably resulted from a small change in the pole of rotation that led to the clockwise realignment of the West Scotia Ridge axis (Fig. 2), which became oblique to the older fabric after ca. $8 \mathrm{Ma}$, judging by magnetic anomalies on the ridge flanks.

In the case of a typical right-stepping ridge-transform-ridge offset, a clockwise rotation of the spreading vector would cause extension on the active transform and no differential motion on the fracture-zone extensions. However, in the unusual situation at the Shackleton Fracture Zone, in which inactive fracture zone extensions were absent, clockwise rotation of the West Scotia Ridge spreading vector, independent of Phoenix Ridge spreading to the southwest, would have led to transpression along the fracture zone southeast of its intersection with the West Scotia Ridge. The continuing, albeit slow, convergence between the Antarctic and Scotia plates (Fig. 2), following Phoenix Ridge extinction, may mean that uplift is continuing today.

This interpretation implies that Antarctic Circumpolar Current flow is much more constricted at Drake Passage today than during the 
Miocene, prior to uplift of the transverse ridge. Moreover, any barrier to circumpolar flow at this pinch point would have disappeared soon after seafloor spreading commenced at the West Scotia Ridge. This event is not precisely dated, but must have been earlier than $29 \mathrm{Ma}$, the age of the earliest identified magnetic anomalies, and certainly much earlier than the 23.5 Ma date of Barker and Burrell (1977). Hence, thermal isolation of Antarctica by the development of the Antarctic Convergence and onset of the Antarctic Circumpolar Current remains a prime candidate for the underlying mechanism driving global changes in circulation and climate at the Eocene-Oligocene boundary.

\section{ACKNOWLEDGMENTS}

We thank Y. Kim, Korea Ocean Research and Development Institute, for supplying seismic profiles acquired by R/V Onnuri and Marco Ligi of the Istituto di Scienze Marine, Bologna, Italy, for providing the profile across the Vema Fracture Zone. We also thank Phil Leat and Neil Mitchell for comments and suggestions. The manuscript has benefited from careful reviews by J.R. Toggweiler, E.J.W. Jones, and R.A. Pockalny.

\section{REFERENCES CITED}

Barker, P.F., 2001, Scotia Sea regional tectonic evolution: Implications for mantle flow and palaeocirculation: Earth-Science Reviews, v. 55, p. 1-39

Barker, P.F., and Burrell, J., 1977, The opening of Drake Passage: Marine Geology, v. 25, p. 15-34.

Bonatti, E., 1978, Vertical tectonism in oceanic fracture zones: Earth and Planetary Science Letters, v. 37, p. 369-379.

Bonatti, E., Ligi, M., Gasperini, L., Peyve, A., Raznitsin, Y., and Chen, Y.J., 1994, Transform migration and vertical tectonics at the Romanche Fracture-Zone, equatorial Atlantic: Journal of Geophysical Research, v. 99, p. $21,779-21,802$.

Bonatti, E., Ligi, M., Brunelli, D., Cipriani, A., Fabretti, P., Ferrante, V., Gasperini, L., and Ottolini, L., 2003, Mantle thermal pulses below the MidAtlantic Ridge and temporal variations in the formation of oceanic lithosphere: Nature, v. 423, p. 499-505.

Coney, P.S., Jones, D.L., and Monger, J.W.H., 1980, Cordilleran suspect terranes: Nature, v. 288, p. 329-333.

DeConto, R.M., and Pollard, D., 2003, Rapid Cenozoic glaciation of Antarctica induced by declining atmospheric $\mathrm{CO}_{2}$ : Nature, v. 421, p. 245-249.

Deschamps, A.E., Lallemand, S.E., and Collot, J.Y., 1998, A detailed study of the Gagua Ridge: A fracture zone uplifted during a plate reorganisation in the mid-Eocene: Marine Geophysical Researches, v. 20, p. 403-423.

Eagles, G., 2000, Modelling plate kinematics in the Scotia Sea [Ph.D. thesis] Leeds, UK, University of Leeds, $304 \mathrm{p}$.

Eagles, G., 2003, Tectonic evolution of the Antarctic-Phoenix plate system since 15 Ma: Earth and Planetary Science Letters, v. 217, p. 97-109.

Engdahl, E.R., van der Hilst, R., and Buland, R., 1998, Global teleseismic earthquake relocation with improved travel times and procedures for depth determination: Seismological Society of America Bulletin, v. 88, p. $722-743$.

Exon, N., and 28 others, 2002, Drilling reveals climatic consequences of Tasmanian Gateway opening: Eos (Transactions, American Geophysical Union), v. 83, p. 253, 258-259.

Flores-Márquez, E.L., Surinach, E., Galindo-Zaldivar, J., and Maldonado, A., 2003, Three-dimensional gravity inversion model of the deep crustal structure of the central Drake Passage (Shackleton Fracture Zone and West Scotia Ridge, Antarctica): Journal of Geophysical Research, v. 108, no. B9, 2445, doi: 10.1029/2002JB001934.

Gasperini, L., Bernoulli, D., Bonatti, E., Borsetti, A.M., Ligi, M., Negri, A., Sartori, R., and von Salis, K., 2001, Lower Cretaceous to Eocene sedimentary transverse ridge at the Romanche Fracture Zone and the opening of the equatorial Atlantic: Marine Geology, v. 176, p. 101-119.

Kamenetsky, V.S., Everard, J.L., Crawford, A.J., Varne, R., Eggins, S.M., and Lanyon, R., 2000, Enriched end-member of primitive MORB melts: Petrology and geochemistry of glasses from Macquarie Island (SW Pacific): Journal of Petrology, v. 41, p. 411-430.

Kastens, K., Bonatti, E., Caress, D., Carrara, G., Dauteuil, O., Frueh-Green, G., Ligi, M., and Tartarotti, P., 1998, The Vema Transverse Ridge (central Atlantic): Marine Geophysical Researches, v. 20, p. 533-556.

Kennett, J.P., 1977, Cenozoic evolution of Antarctic glaciation, the circumAntarctic Ocean, and their impact on global paleoceanography: Journal of Geophysical Research, v. 82, p. 3843-3859.

Kennett, J.P., Houtz, R.E., Andrews, P.B., Edwards, A.E., Gostin, V.A., Hajos,
M., Hampton, M., Jenkins, D.G., Margolis, S.V., Ovenshine, A.T., and Peach-Nielson, K., 1975, Cenozoic paleoceanography in the southwest Pacific Ocean, Antarctic glaciation, and the development of the circumAntarctic current, in Kennett, J.P., Houtz, R.E., et al., Initial reports of the Deep Sea Drilling Project, Volume 29: Washington, D.C., Government Printing Office, p. 1155-1169.

Kim, Y., Jin, Y.K., and Nam, S.H., 1997, Crustal structure of the Shackleton Fracture Zone in the southern Drake Passage, Antarctica, in Ricci, C.A., ed., The Antarctic region: Geological evolution and processes: Siena, Terra Antarctica Publications, p. 661-667.

Klepeis, K.A., and Lawver, L.A., 1996, Tectonics of the Antarctic-Scotia plate boundary near Elephant and Clarence Islands, West Antarctica: Journal of Geophysical Research, v. 101, p. 20,211-20,231.

Lawver, L.A., and Gahagan, L.M., 1998, Opening of Drake Passage and its impact on Cenozoic ocean circulation, in Crowley, T.J., and Burke, K.C., eds., Tectonic boundary conditions for climate reconstructions: Oxford, Oxford University Press, p. 212-223.

Livermore, R.A., McAdoo, D., and Marks, K., 1994, Scotia Sea tectonics from high-resolution satellite gravity: Earth and Planetary Science Letters, v. 123 , p. $255-268$.

Livermore, R., Balanya, J.C., Maldonado, A., Martinez, J.M., RodriguezFernandez, J., de Galdeano, C.S., Zaldivar, J.G., Jabaloy, A., Barnolas, A., Somoza, L., Hernandez-Molina, J., Surinach, E., and Viseras, C., 2000, Autopsy on a dead spreading center: The Phoenix Ridge, Drake Passage, Antarctica: Geology, v. 28, p. 607-610.

Maldonado, A., Balanya, J.C., Barnolas, A., Galindo-Zaldivar, J., Hernandez, J., Jabaloy, A., Livermore, R., Martinez-Martinez, J.M., RodriguezFernandez, J., de Galdeano, C.S., Somoza, L., Surinach, E., and Viseras, C., 2000, Tectonics of an extinct ridge-transform intersection, Drake Passage (Antarctica): Marine Geophysical Researches, v. 21, p. 43-68.

Mikolajewicz, U., Maierreimer, E., Crowley, T.J., and Kim, K.Y., 1993, Effect of Drake and Panamanian Gateways on the circulation of an ocean model: Paleoceanography, v. 8, p. 409-426.

Nong, G.T., Najjar, R.G., Seidov, D., and Peterson, W.H., 2000, Simulation of ocean temperature change due to the opening of Drake Passage: Geophysical Research Letters, v. 27, p. 2689-2692.

Pearce, J.A., Leat, P.T., Barker, P.F, and Millar, I.L., 2001, Geochemical tracing of Pacific-to-Atlantic upper-mantle flow through the Drake Passage: Nature, v. 410 , p. $457-461$.

Pelayo, A.M., and Wiens, D.A., 1989, Seismotectonics and relative plate motions in the Scotia Sea region: Journal of Geophysical Research-Solid Earth and Planets, v. 94, p. 7293-7320.

Pockalny, R.A., 1997, Evidence of transpression along the Clipperton transform: Implications for processes of plate boundary reorganization: Earth and Planetary Science Letters, v. 146, p. 449-464.

Pockalny, R.A., Fox, P.J., Fornari, D.J., Macdonald, K.C., and Perfit, M.R., 1997, Tectonic reconstruction of the Clipperton and Siqueiros Fracture Zones: Evidence and consequences of plate motion change for the last 3 Myr: Journal of Geophysical Research, v. 102, p. 3167-3181

Prince, R.A., and Forsyth, D.W., 1988, Horizontal extent of anomalously thin crust near the Vema Fracture Zone from the three-dimensional analysis of gravity anomalies: Journal of Geophysical Research, v. 93, p. 8051-8063.

Sandwell, D.T., and Smith, W.H.F., 1997, Marine gravity anomaly from Geosat and ERS-1 satellite altimetry: Journal of Geophysical Research, v. 102, p. $10,039-10,054$

Sijp, W.P., and England, M.H., 2004, Effect of the Drake Passage throughflow on global climate: Journal of Physical Oceanography, v. 34, p. 1254-1266.

Smith, A.G., 1999, Gondwana: Its shape, size and position from Cambrian to Triassic times: Journal of African Earth Sciences, v. 28, p. 71-97.

Sun, S.S., and McDonough, W.F., 1989, Chemical and isotopic systematics of oceanic basalts: Implications for mantle composition and processes, in Saunders, A.D., and Norry, M.J., eds., Magmatism in the ocean basins: Geological Society [London] Special Publication 42, p. 313-345.

Thomas, C., Livermore, R.A., and Pollitz, F., 2003, Motion of the Scotia Sea plates: Geophysical Journal International, v. 155, p. 789-804.

Zachos, J., Pagani, M., Sloan, L., Thomas, E., and Billups, K., 2001, Trends, rhythms, and aberrations in global climate $65 \mathrm{Ma}$ to present: Science, v. 292 , p. $686-693$.

Manuscript received 4 February 2004

Revised manuscript received 30 April 2004

Manuscript accepted 30 April 2004

Printed in USA 